\title{
Role of maritime ports and shipping in the creation of the economic value of the sea areas
}

\author{
Jacek Zaucha ${ }^{1}$, and Maciej Matczak ${ }^{2}$ \\ ${ }^{1}$ University of Gdańsk, Faculty of Economics, 119/121Armii Krajowej str., 81-824 Sopot, Poland \\ ${ }^{2}$ Gdynia Maritime University, Faculty of Entrepreneurship and Quality Science, 81-87 Morska Str., \\ 81-225 Gdynia, Poland
}

\begin{abstract}
The sea coast location of a country has been regarded as a critical value for its development and prosperity for years. It relates to economic, military, and environmental issues. A wide scope of economic activities, like shipping and maritime ports, fishing and aquaculture, underwater mining (e.g., oil, gas, sand) and sea coast tourist activities all require access to the sea. The sea area should also be regarded as a limited resource thus the activities need to compete for maritime space. Today, comprehensive economic valuation of selected activities, both from the private and public point of view, became significantly important. The aim of this article is an attempt to evaluate the economic value of maritime space, which is generated by ports and shipping. Initially, review of the literature regarding the valuation of economic effects of maritime port and shipping was carried out. The analysis has been based on a model of the interrelation between ports and shipping and its socio-economic environment. Then, redefinition and extension of identified values to the sea areas were provided. Finally, a calculation of the unit value of sea space [PLN per sq. $\mathrm{km}$ ] as well as identification of most valuable spatial parts of the sea was completed. The application part of the study was based on the example of Polish seaports as well as Polish maritime areas on the Baltic Sea.
\end{abstract}

\section{Methodology approach}

The aim of this article is an attempt to evaluate the economic value of maritime space which is created by ports and shipping sector. For that purpose, the following stages of research were implemented:

- Investigation of current achievements regarding valuation of the impact of the maritime sector on the socio-economic development by review of relevant literature.

- Identification of the key types and sources of spatial rents from the maritime sector.

- Development of the model of the interrelation between the seaport and shipping sector and its socio-economic environment.

- Investigation of the value created by the sector with a focus on gross added value and gross financial results.

- Recalculation of the unit value of maritime space in Poland [PLN per sq km]. 
- Transfer of results to maps illustrating the space distribution of values as well as identification of most valuable spatial parts of the Baltic Sea (the Polish internal waters part).

The empirical part of the study was based on the case of the Polish maritime sector, which resulted mainly from the availability of detailed information necessary to carry out the study.

\section{Socio-economic impact of the shipping and port industry development in research}

The impact of shipping and seaport sector on the socio-economic activity is undeniable. The history of human development and civilisation growth is directly connected with the access to the seas. Thus, development of studies concerning interrelations between maritime transport (shipping and ports) and its surroundings, including socio-economic development, could be noted. Considering the key areas of research, the following levels of analyses can be distinguished:

- port-city relations \& policies,

- maritime ports versus regional and countries economy development,

- ports and shipping in the global economy.

Referring to the first scope of analysis, spatial development should be regarded as the main area of the researcher's interest [1-5]. Despite the relevant identification of interactions, this type of research does not valuate the impact on the socio-economic level in the monetary terms.

The interrelation between regional and national economic system constitutes the second level of investigation. In that respect, two issues are considered - the role of maritime ports in economic development (defined as an engine for gross domestic product or gross added value increase) at regional and country level [6-10] and its place in the creation of the labour market [11]. Commonly discussed issue, in that respect, is the direction of influence. On the one hand, the ports are regarded as an accelerator of regional and country economy, on the other they are treated only as a response to an economic demand from a socio-economic system [12]. For the needs of this study, the first approach is adopted.

The role of maritime transport and seaport in economic development is also researched on the global scale. Considering the main area of research, the problem of transport cost is dominating. In this case, the transport is regarded as an issue restricting the volume of external trade [13]. Similarly, international trade, a vital element of GDP calculation (net export within the expenditure approach), is also considered as a necessary element for further development of the national economy. Thus effective transport can be treated as an accelerator of growth.

All in all, investigation of value created by sea areas is strictly connected with the second level of analysis, so further research is conducted according to that approach.

\section{Economic valuation of the sea space - issue of maritime ports and shipping}

Valuation of benefits deriving from the use of sea space and the costs of obtaining them is important for knowing the spatial rental, which was considered one of the most important mechanisms for shaping the maritime space.

As part of market processes, the spatial rent can be considered as private (private spatial rent). Such approach can be understood as the tendency of the user of the space to pay for its use (the so-called bid-rent), assuming that the level of utility/profit remains constant. 
Otherwise, in public selection processes, the rent can have a public nature. It can be equated with the difference between social benefits (private benefits and external benefits) and social costs (private costs and social loss). Both rentals, private and social (public), can vary significantly. For the progress and development of spatial economics, analyzing these differences may have a high cognitive significance, but from the point of view of the development of the maritime space, this is not so important [14].

A private pension remains an important mechanism where the legislator has allowed the market advantage (e.g., maritime transport, tourist or fishing), and public rent where public choice is of primary importance (environmental protection, wind energy, mineral extraction, etc.). Differences between both types of rent for a given method of benefiting from the sea space, serve to verify the validity of these decisions. For example, decisions limiting the uncontrolled development of coastal tourism prove that the legislator sees the difference between its public and private rents. These differences are also an important decision-making parameter when the public administration makes administrative decisions on changing the use of sea areas (in a situation where new ways exclude pre-existing ones). For example, the occupation of fishery areas for wind farms should be preceded by a comparison of the public pension from both uses of sea areas.

The scale of difficulty in obtaining a reliable annuity index increases with the decrease in the possibility of using a market valuation for this purpose. This is due to the problem of spatial attribution of economic data. Considering the main areas of socio-economic activity provided within (or on base) the sea areas, the following sectors could be distinguished:

- fishing,

- coastal tourism,

- seaports and shipping,

- denitrification services of marine sediments,

- offshore wind energy [14].

In that respect, the possibility of calculating the level of spatial rent for listed sectors differs significantly. As per the initial assumption, the study is focused on the ports and shipping activities. There is a possibility of market pricing of private benefits and costs but to a limited extent. Their spatial attribution is complicated; private rent is more important, but public rent also seems important due to the considerable support of public authorities for the port sector. Further identification of spatial rent from those sectors required identification and valuation of their socio-economic benefits on the national level.

\section{Economic value of maritime ports and shipping industry in Poland}

A comprehensive valuation of socio-economic benefits from maritime transport development requires definition and quantification of the basic relations occurring between seaports and the regions or countries of their location. The implementation of this goal requires multifaceted and a multidimensional view of the functioning of modern seaports. The Oxford Economics research is an example of a similar relationship $[15,16]$. The authors divide the impact of port sector between three levels: a direct impact, indirect impact and induced effects. The results of port activity were evaluated from labor market, national accounts as well as exchequer revenues. Worth noting is the fact that such a method allows the determination of multiplier effects. Because of lack of access to relevant sources of information, a modified approach has been adopted in this study.

Analysis of the functional structure of Polish seaports, as well as its verification from the point of view of the availability of information, allow to define a four-layer model (Fig. 1) of port sector [17]: 
- First level: MARITIME PORT,

- Second level: SEAPORT SECTOR (incl. maritime ports),

- Third level: DIRECT PORT ENVIRONMENT (incl. port sector),

- Fourth level: SOCIO-ECONOMIC PORT ENVIRONMENT (incl. direct port environment).

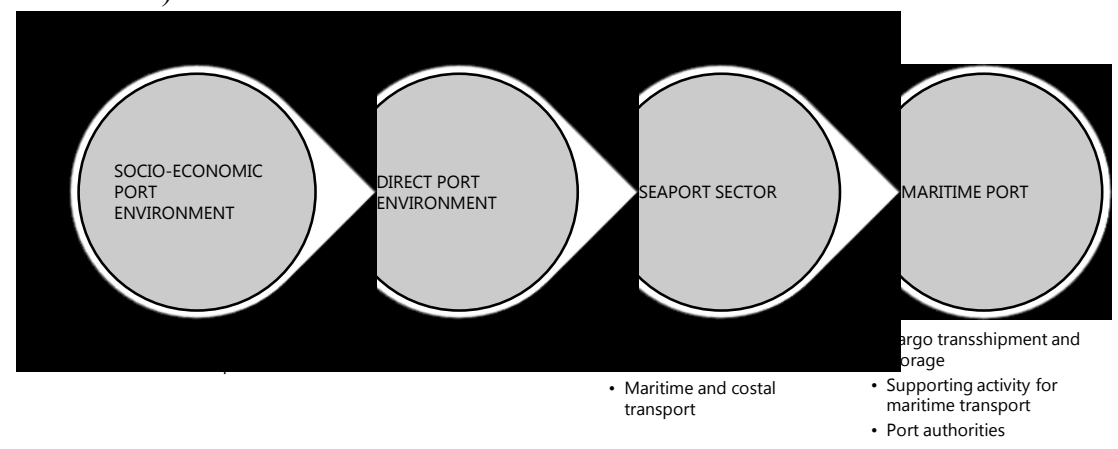

Fig. 1. Model of interrelation between ports and socio-economic environment Source: Matczak 2017

Such an approach allows taking into account the fact that the real beneficiaries of sea transport and transshipment are Polish companies importing and exporting goods by sea. Their private (monetary) net benefit from the existence of sea space is the difference between their profits obtained by using maritime transport and profits that would be possible using other modes of transport that do not use ports, anchorages and sea routes, and those using foreign ports. In practice, this figure can't be empirically calculated, or it would require very extensive and often time-consuming research, hence the simplified method of GVA estimation has been used. Comprehensive investigation based on the data from the Central Statistical Office in Poland has been completed within the study [18].

The total GVA of PLN 1619.7 million (an increase of $2.7 \%$ compared to the previous year) was generated in Poland in 2016. The regions of the main seaport locations in PolandPomerania and West Pomerania were responsible for $5.7 \%$ and $3.7 \%$ of country GVA respectively.

Based on the parameters of the labor market in the port sector and its environment as well as the average GAV generated in specific port regions by one employee [19], the level of gross value added in individual areas of the analysis was estimated.

Taking into account the broadest view of the effects of seaport activities (Level IV) covering both seaports, port sector, and the immediate and economic environment of ports, the value of PLN 32,155.02 million was generated in 2016. When comparing the results to the national GVA, it can be said that $1.99 \%$ of the value in the country is created by port operations, which should be considered significant.

The results obtained can be directly related to the share of the port sector and its environment in generating gross domestic product.

Worth noting here is the fact that results obtained are based on the average values assigned to particular areas of analysis, which in the light of the above-average level of value creation in the transport sector allows us to suppose that the real impact is greater.

Another method of assessing the value of maritime space implemented in the research is an investigation of the gross financial results of companies engaged in the seaport and shipping sector. Information on the financial results of shipping and ports is also available in the annual statistics of the maritime economy [18]. They only include, unfortunately, maritime enterprises registered in Poland, with accounting books in which the number of employees exceeds 9 persons. Information on the gross financial result is available by type 
of activity, and the following should be included in those related to maritime transport: reloading, storage and storage of goods in seaports, other activities supporting maritime transport, operations of maritime transport agencies, seaports, maritime and coastal water transport.

In 2016, the gross financial result of enterprises conducting the abovementioned type of activities amounted to PLN 874,1 million. This approach is conservative. It does not include multiplier effects, such as indicating how ports and shipping stimulate their economic environment.

\section{Valuation of the maritime space - Poland's case}

As was previously touched, free navigation on the seas is the main reason for leading importance of private rent in maritime transport. The public rent differs from it because its value is greater by very significant external benefits (multiplier effects) and costs. Social losses from shipping include those related to the use and degradation of the environment (e.g., oil spills, worsening of the welfare of marine fauna, atmospheric pollution, introduction of alien species). Even if their monetary value could be obtained, their spatial attribution will always be subjective. For example, atmospheric pollution in ports may be lower than on the high seas if the port uses electric assistance for ships entering it.

Also, the pricing of private rent is not easy. At sea, there is also a complication related to the fact that the law of the sea (UNCLOS) guarantees (with certain exceptions, e.g., traffic separation zones) free access to sea areas to ships of all flags. Therefore, foreign shipping companies benefit from maritime areas for free, and their activity does not benefit the national economy if these ships do not call at those relevant ports. Only environmental costs appear. The rent from transit shipping routes is therefore of an international nature. It is difficult to estimate it using the national economic information available in the country. However, if foreign shipping companies support Polish exchange of goods, it is true that their profits do not create the wealth for their country, but they contribute to the development of the Polish economy.

All this makes it very difficult to calculate the spatial rent from the existence of ports and sea routes connecting them. What is more, a different construction of categories: gross financial result (PLN 740.3 million) and gross value added (PLN 29,295.29 million) causes a significant difference between the presented values. In case of gross financial result,, a difference between revenues and costs is estimated, thus in case of GVA, a difference between global output and intermediate consumption is used.

The above-mentioned value of GVA and gross financial result was assigned to individual ports on the basis of the average size of their reloading in the years 2005-2015 [20] ${ }^{*}$.

The methods of assigning the value of gross financial result in their spatial attribution are shown in Table 1. The assumption was made that the port cannot function without the necessary space of sea areas, which includes sea basins, roads, anchorages, and flaps serving a given port. All elements of this space are equally valuable. It was also assumed that the Szczecin-Police-Świnoujście port complex is served by the common sea area. On the basis of existing documents, it was not possible to distinguish such areas for small ports, with the exception of Kołobrzeg. It was also assumed that the ship must use both the space serving the port directly and the shipping lanes. Therefore, $50 \%$ of GVA and the gross financial result of maritime transport were assigned to these routes, and 50\% to marine areas serving the ports directly.

\footnotetext{
* Presented approach should be considered simplificd, as it can be assumed that the containerized cargo provides a higher gross financial result per unit weight of the load. The proposed division does not take this fact into account
} 
Table 2. Value of spatial rent for sea areas serving ports based on GVA and gross financial result in 2015 .

\begin{tabular}{|c|l|r|r|r|r|r|r|}
\hline No & \multicolumn{1}{|c|}{ PORT } & $\begin{array}{r}\text { Port share } \\
\text { in total } \\
\text { turnover } \\
\text { in\% } \\
\text { average } \\
\text { 2005-2015) }\end{array}$ & $\begin{array}{c}\text { Gross } \\
\text { financial } \\
\text { result } \\
\text { assigned to } \\
\text { a port in } \\
\text { PLN } \\
\text { million in } \\
\text { 2015 }\end{array}$ & $\begin{array}{c}\text { Gross value } \\
\text { added } \\
\text { attributed to } \\
\text { a given port } \\
\text { in PLN } \\
\text { million in } \\
2015\end{array}$ & $\begin{array}{c}\text { The sea } \\
\text { area that } \\
\text { serves the } \\
\text { port directly } \\
\text { [sq. km] }\end{array}$ & $\begin{array}{c}\text { Gross } \\
\text { financial result } \\
\text { per sq km of } \\
\text { Polish sea } \\
\text { areas serving a } \\
\text { given port in } \\
\text { PLN }\end{array}$ & $\begin{array}{c}\text { Gross added } \\
\text { value per sq km } \\
\text { of Polish sea } \\
\text { areas serving a } \\
\text { given port in } \\
\text { PLN }\end{array}$ \\
\hline \multicolumn{1}{|l|}{ Total } & 100.00 & 740.3 & $29,295.29$ & $15,435.00$ & & \\
\hline 1 & Gdańsk & 39.68 & 146.9 & $5,812.19$ & 166.4 & $882,665.38$ & $34,928,999.62$ \\
\hline 3 & Gdynia & 24.64 & 91.2 & $3,609.18$ & 35.41 & $2,575,683.71$ & $101,925,437.11$ \\
\hline 5 & Police & 32.08 & 118.7 & $4,698.96$ & 223.33 & $580,923.19$ & $22,988,400.90$ \\
\hline 6 & Kołobrzeg & 2.97 & 11.0 & 435.04 & & & \\
\hline 7 & Other ports & 0.25 & 0.9 & 36.62 & 17.11 & $54,083.87$ & $2,140,216.98$ \\
\hline
\end{tabular}

Source: Own calculation based on the data \& information from above presented sections and the Central Statistical Office in Poland [18]

Table 1 presents the spatial rent for ports based on GVA and gross financial result. The latter approach underestimates the significance of sea areas used for port purposes, since it omits other port operations, aside from transshipments. In GVA approach, additional types of maritime related activities are taken into account, e.g., scientific research, sea mining (oil), construction of water engineering facilities for maritime economy, architecture, engineering for maritime economy, renting water transport, consultancy, research and analysis technical, recruitment of employees and other activities for maritime economy. Unfortunately, this is not recognized by the GUS financial result indicator.

The level of the annuity with the use of the gross financial result varies from over PLN 2.58 million for the port in Gdynia to PLN 54.08 thousand for the port in Kołobrzeg. For the GVA, this spatial rent is PLN 101.93 million, respectively, up to PLN 2.14 million.

The calculation of the spatial rent of shipping lanes in Polish sea areas was made on the basis of information on the intensity of ship traffic in these areas. AIS information was used, a system which allows to indicate the frequency of passage of the ship through sea squares with an area of approx. 1 square $\mathrm{km}$. Spatial rent is calculated as the product of the number of vessels passing through a square and GVA during the year, or the gross financial result of one crossing calculated as $50 \%$ of their total value in 2015 for Polish sea areas and the sum of all transitions through all AIS squares in these areas. In 2015, there were a total of $5,108,559$ such transfers for all squares, and the value of one passage through the square was PLN 72.4 for the gross financial result and PLN 2.87 thousand PLN for GVA. 


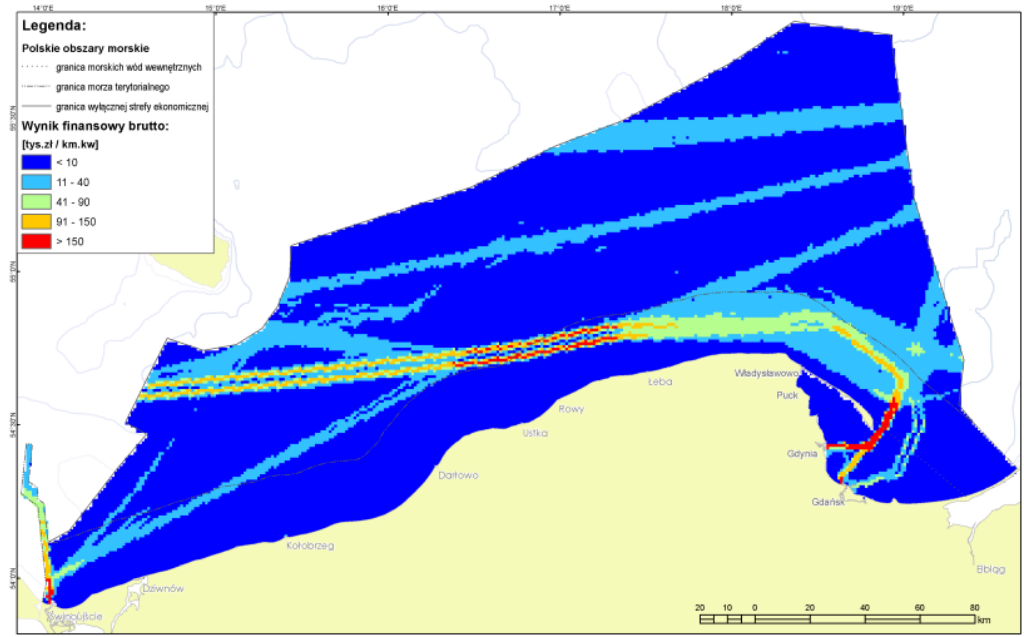

Fig. 4. Spatial rent from shipping routes for 2015 using the gross financial result of shipping and ports [14]

The highest value of the estimated shipping rent is about 281 thousand PLN per sq. $\mathrm{km}$ for the gross financial result and PLN 11,604 thousand per sq. km for GVA. The average value is PLN 11 thousand and 472 thousand PLN respectively. Figures 4 and 5 contain a graphic image of a spatial rent from commercial shipping.

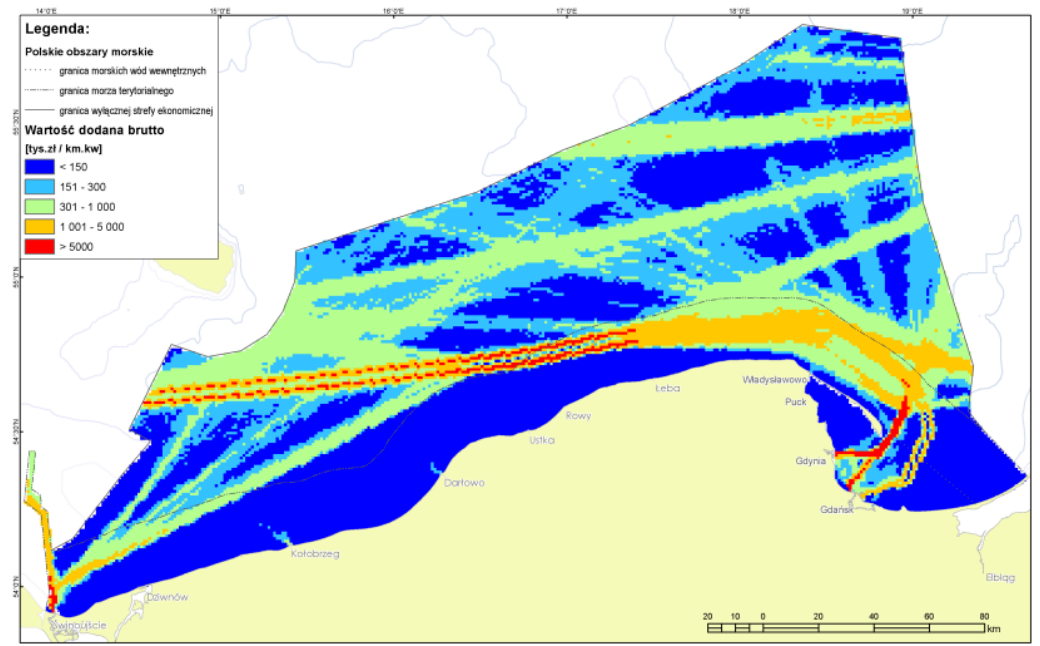

Fig. 5. Rent from shipping routes for 2015 using WDB for port sector and its business environment [14]

The intensity of shipping in both engravings is the same, and the apparent differences result from the adoption of different limit values for rents illustrated in both drawings. The estimates presented above overstate the rent, as they assume that ships only use Polish sea areas and Polish ports. In fact, depending on the distance that a ship has to travel, this type of disbursement should be spread over the entire shipping route. Such calculations based on information from AIS would, however, be significantly complicated and costly. 


\section{Conclusions}

Estimation of the value of access to the sea areas is an important element of modern maritime policy, because the need to make rational choices related to the management of the sea is very important. Maritime areas are used to implement a number of economic and social activities, which create benefits and costs for society, economy and environment. Reliable assessment of the impact of such activities allows for better use of marine space and thus contributes to the development of the economy and prosperity.

This article presents an attempt at a valuation of the sea areas pertaining to transport activities. The results obtained indicate a number of problems and challenges that limit the analytical possibilities. On the one hand, it is an access to relevant data, as well as their scope and quality. The second is the different ways of assessment of the value created by the maritime transport sector, as indicated by discrepancies in the results obtained. For instance, the calculation based on the GVA created by ports and shipping in Poland reached level of PLN 29,295.29 million in 2015. At the same time, the value based on the gross financial results of the sector companies reach PLN 740.3 million. A significant gap is also identified in the case of particular maritime ports. The level of the annuity with the use of the gross financial result varies from over PLN 2.58 million per sq. meter for the port in Gdynia to PLN 54.08 thousand per sq. meter for the port in Kołobrzeg.

An important issue, deliberately omitted in the study, is the comparability of results from various areas of activity (e.g. tourism, fishing).

There is no doubt that the valuation of access to sea areas requires further research and analysis, which should bring further approximations to their final, reliable determination.

\section{References}

1. T. Palmowski, M. Pacuk, T. Michalski, Przemiany przestrzeni miast portowych na przykładach Gdańska i Gdyni, XIV Konwersatorium Wiedzy o Mieście (2001) https://depot.ceon.pl/bitstream/handle/123456789/5469/Przemiany przestrze ni miejskiej miast_portowych na przyk\%C5\%82adach_Gda\%C5\%84ska i G dyni.pdf?sequence $=1$ \&isAllowed $=y$

2. P. Lorens, Obszary Portowe - problemy rewitalizacji, ISR, Szczecin (2013) https://arch.pg.edu.pl/documents/174968/51761959/poportowe.pdf

3. K. Krośnicka, Wpływ działalności portów na strukturę funkcjonalno-przestrzenną miast, Inż. Mor. i Geotech. 5, (2012)

4. K. Krośnicka, Ewolucja relacji port-miasto na tle rozwoju technologii żeglugi, Publishing House of Gdynia Maritime University (2005)

5. Współzależność funkcjonowania portu i miasta portowego (w warunkach gospodarki rynkowej), Edit. B. Szwankowska, Publishing House of Maritime Institute, No. 4946, Gdańsk (1994).

6. Ferrari, C., Merk, O., Bottasso, A., Conti, M., Tei, A. (2012), Ports and Regional Development: a European Perspective, OECD Regional Development Working Papers, (2012), OECD Publishing http://dx.doi.org/10.1787/5k92z71jsrs6-enA.

7. C. Ferrari, Ports and regional economic development, Global Ports and Urban Development: Challenhes and Opportunities, OECD, Paris (2011), OECD Publishing www.oecd.org/gov/regional-policy/49456330.pdf 
8. G.s. Dwarakish, Akhli Muhamman Salim, Rewiev on the Role of Ports in the Development of a Nation, Aquatic Procedia, 4 (2015), pp. 295-301.

9. Q. Sakalayen, The Strategic Role of Australian Ports in Regional Development, Univ. of Tasmania (2014) https://eprints.utas.edu.au/18706/5/WholeSakalayen-thesis ex pub mat.pdf

10. L. Berkoz, D. Tekba, The Role of Ports in the Economic Development of Turkey, $39^{\text {th }}$ European Congress of the regional Science Association (1999) https://pdfs.semanticscholar.org/9abe/14d3487645c81729506f0d8f73a19b9cb 0f1.pdf

11. Ports: job generation in the context of regional development, Department of Infrastructure and regional Development, Australian Governance, Information sheet 56 (2014)

12. B-m. Jung, Economic Contribution of Ports to the Local Economies in Korea, The Asian Journal of Shipping and Logistics, Vol. 27, No. 1, pp. 001-030 (2011)

13. P.R. Krugman, M. Obstfeld, M.J. Melitz, International Economics Theort \& Policy, Addison-Wesley (2012),

14. J. Zaucha, Gospodarowanie przestrzenią morską, Academic Publishing House Sedno, Warsaw (2018).port

15. The economic impact of the UK Maritime Service Sector, A Report for Maritime UK, Oxford Economics (2012)

16. The economic impact of the UK Maritime Service Sector: Ports, A Report for Maritime UK, Oxford Economics (2012)

17. M. Matczak, Polskie porty morskie jako biegun rozwoju gospodarczego kraju I regionów lokalizacji, Raport: Rada Interesantów Portu Gdynia/Baltic Container Terminal Gdynia/Actia Forum (2017)

18. Statistical Yearbook of Maritime Economy 2017, Central Statistical Office, Statistical Office in Szczecin (2017)

19. Local Data Bank, Centra Statictical Office, Warsaw (2017) https://bdl.stat.gov.pl/BDL/start

20. M. Matczak, Polish seaports in year 2015. Summary and future prospects, Actia Forum (2016) 